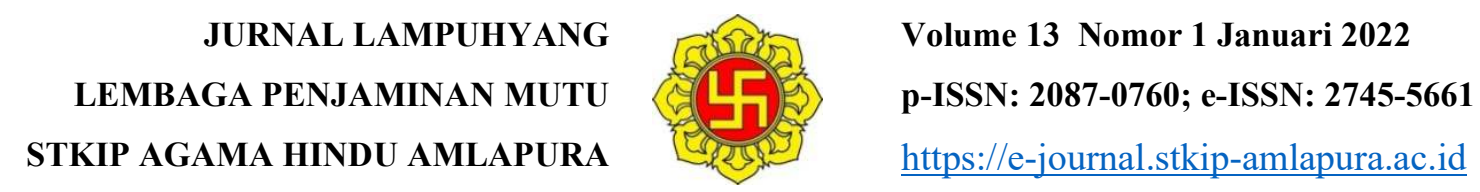

\title{
Analisis Struktural dan Nilai Pendidikan Karakter pada Buku Cerita Bergambar "Pajak Kita" serta Relevansinya terhadap Kemajuan Bangsa Indonesia
}

\author{
Sang Ayu Putu Nilayani \\ STKIP Agama Hindu Amlapura \\ Sangayutu08@gmail.com
}

Direvisi: 22 November 2021

Diterima: 24 Desember 2021

Diterbitkan: 1 Januari 2022

\begin{abstract}
Abstrak: Penelitian ini bertujuan untuk mengetahui unsur instrinsik dan ekstrinsik, nilai pendidikan karakter yang terkandung dalam Buku Cerita Bergambar Pajak Kita dan untuk mengetahui relevansi Buku Cerita Bergambar Pajak Kita tehadap kemajuan Bangsa Indonesia. Teknik pengumpulan data adalah analisis dokumen. Diperoleh hasil penelitian bahwa Buku Cerita Bergambar "Pajak Kita" memiliki unsur instrinsik, yaitu unsur dalam pembangun sebuah karya sastra. Unsur-unsur tesebut adalah unsur tema, amanat, latar, alur, tokoh, dan penokohan. Ketiga cerita dalam Buku Cerita Bergmabar "Pajak Kita" mengandung nilai-nila pendidikan karakter yang tergambar jelas dalam cerita. Nilai-nila tesebut adalah nilai tanggung jawab, nilai kerja keras, ketekunan, kerja sama, kedisiplinan, keiklasan dan kemandirian, nila gotong royong, dan lain-lain. Nilai-nilai ini sangat berpengaruh besar tehadap perkembangan karakter anak sejak dini. Buku Cerita Begambar "Pajak Kita" sangat relevan dengan perkembangan Bangsa Indonesia. Dalam cerita yang tedapat pada buku bergambar ini mengajarkan nilai-nila karakter yang positif yang tentu akan berpengaruh besar terhadap perkebangan Bangsa Indonesia kelak. Salah satu yang paling relevan adalah cerita dengan judul "Sang Raja dengan Sesendok Madu". Cerita ini sangat berkaitan erat dengan pembayaran pajak di negara kita, yakni membayar pajak adalah salah satu tanggung jawab rakyat yang nantinya akan dinikmati sediri oleh rakyat. Cerita ini tentu akan menjadi pengaruh besar terhadap rasa tanggung jawab anak yang nantinya akan diaplikasikan ketika anak sudah besar.
\end{abstract}

Kata Kunci : Analisis, Pendidkan Karakter, Buku Cerita Bergambar "Pajak Kita"

Abstract: This study aims to determine the intrinsic and extrinsic elements, the value of character
education contained in the Tax Kita Picture Story Book and to find out the relevance of the Tax
Kita Picture Story Book to the progress of the Indonesian nation. Data collection technique is
document analysis. The results of the research show that the Picture Story Book "Our Tax" has an
intrinsic element, namely the element in building a literary work. These elements are elements of
theme, mandate, setting, plot, characters, and characterizations. The three stories in the Illustrated
Storybook "Our Taxes" contain character education values which are clearly illustrated in the
stories. These values are the value of responsibility, the value of hard work, perseverance,
cooperation, discipline, sincerity and independence, the value of mutual cooperation, and others. 
These values have a great influence on the development of children's character from an early age. The illustrated story book "Our Taxes" is very relevant to the development of the Indonesian nation. The story contained in this picture book teaches positive character values which will certainly have a big influence on the development of the Indonesian nation in the future. One of the most relevant is the story with the title "The King with a Spoon of Honey." This story is closely related to paying taxes in our country, where paying taxes is one of the people's responsibilities which will be enjoyed by the people themselves. This story will certainly be a big influence on the child's sense of responsibility which will later be applied when the child grows up.

\section{Keywords: Analysis, Character Education, Buku Cerita Bergambar "Pajak Kita"}

\section{PENDAhuluan}

Sastra merupakan salah satu karya yang didasarkan pada imajinasi pengarangnya. Sumardjo dan Saini (dalam Rokhamnsyah, 2013:2) menyebutkan bahwa sastra adalah ungkapan pribadi manusia yang berupa pengalaman, pemikiran, perasaan, ide, semangat keyakinan dalam suatu bentuk gambaran konkret yang membangkitkan pesona dengan alat bahasa. Karya sastra merupakan perwujudan nyata imajinasi seorang penulis melalui proses yang beragam.

Dalam menciptakan suatu karya, penulis tidak hanya ingin menghasilkan karya yang indah dan bisa dinikmati, namun penulis juga ingin menyampaikan ide-ide, gagasan serta pandangan mengenai apa yang dirasakan dan dilihat oleh penulis yang kemudian dituangkan dalam sebuah karya sastra atau tulisan. Karya sastra juga menjadi salah satu cara dalam mengungkapkan kehidupan seharihari manusia sehingga tema yang diangkat dalam karya sastra cenderung mengenai masalah-masalah dalam kehidupan manusia, seperti buku cerita bergambar. Buku cerita bergambar ini merupakan karya sastra yang cenderung mengangkat permasalahan-permasalahan mengenai kehidupan manusia, khususnya kehidupan anak-anak, yang mana tujuan penulisan buku cerita bergambar ini adalah untuk membentuk karakter baik bagi anak-anak.

Cerita bergambar sebagai sebuah karya fiksi menawarkan sebuah dunia yang berisi model kehidupan yang diidealkan, dunia imajinatif yang dibangun melalui berbagai unsur intrinsiknya seperti peristiwa plot, tokoh (penokohan), latar, sudut pandang, dan lain-lainnya yang kesemuanya tentu saja juga bersifat imajinatif.

Teori strukturalisme merupakan 
jenis teori sastra yang sudah menjadi "urutan pertama dan utama" dalam pergulatan intelektual khazanah ilmu sastra (Sehandi, 2014: 106). Bahkan, dapat dikatakan bagi setiap peneliti sastra, analisis struktur karya sastra yang ingin diteliti dari sudut manapun merupakan tugas utamanya.

Teeuw (2015:106) menyatakan bahwa tujuan dari analisis struktural adalah membongkar dan memaparkan secermat, seteliti, mendetail, dan mendalam mungkin keterkaitan dan keterjalinan semua anasir dan aspek karya sastra yang menghasilkan makna menyeluruh.

Salah satu pendidikan karakter yang perlu kita ajarkah kepada anak-anak sejak dini adalah Pendidikan anti korupsi. Pendidikan anti korupsi dalam kaitannya dengan karakter anak adalah Pendidikan anti korupsi mengenai hal-hal yang kecil, salah satunya adalah kejujuran, tanggung jawab, disiplin daln lain-lain terhadap sesuatu yang kecil seperti disiplin waktu, jujur dengan teman, dan sebagainya. Pendidikan karakter mengenai anti korupsi ini dapat dilihat dalam Buku Cerita Bergambar "Pajak Kita", untuk lebih memastikan nilai Pendidikan karakter pada Buku Cerita Bergambar "Pajak Kita" serta relevansinya terhadap kemajuan Bangsa Indonesia, perlu adanya penelitian dengan tujuan untuk mengetahui unsur instrinsik dan ekstrinsik, nilai pendidikan karakter, serta relevansi Buku Cerita Bergambar Pajak Kita tehadap kemajuan Bangsa Indonesia.

\section{TINJAUAN PUSTAKA}

\subsection{Unsur Pembangun Sebuah Karya Sastra}

Unsur pembangun sebuah karya sastra adalah unsur ekstrinsik dan intrinsik. Unsur-unsur intrinsik sastra meliputi: tema, alur, suasana, sudut pandang pengisahan, latar, penokohan/perwatakan, (Ngafenan, 1990). Ia berpendapat bahwa tema adalah pokok pembicaraan cerita, pokok persoalan yang mendasari suatu cerita untuk dijabarkan dalam karangan. Penjabaran dapat melalui pengisahan atau dialog para pelaku cerita. Tema dapat bermacammacam tergantung pada selera pengarangnya. Misalnya cinta, kemanusiaan, ketuhanan, adat, kritik sosial, balas dendam.

Unsur intrinsik adalah suatu unsur yang menyusun suatu karya sastra dari dalam yang mewujudkan struktur sebuah 
karya sastra seperti unsur-unsur yang terdapat dalam unsur-unsur intrinsik. Intrinsik itu terdiri dari unsur-unsur seperti: Tema, Alur/plot, Latar/seting, Gaya bahasa. Mengenai tema, Saad dalam Ali (1967:118) berpendapat bahwa tema adalah suatu yang menjadi persoalan bagi pengarang di dalamnya terbayang pandangan hidup dan cita-cita pengarang, bagaimana ia melihat persoalan itu. Selanjutnya, Brooks dan Warren (dalam Trigan,1984:125) menyatakan tema adalah pandangan tertentu mengenai kehidupan atau rangkayan nilai tertentu yang membentuk atau membangun dasar atau gagasan utama dari suatu karya sastra.

Pengertian alur, Sudjiman (1992:43) berpendapat bahwa alur adalah rangkaian peristiwa yang direka dan dijalani dengan saksama yang menggerakkan cerita melalui rumitan ke arah klimaks dan selesaian. Sedangkan Aminudin (1987:83) alur adalah rangkaian peristiwa yang dibentuk oleh tahapan-tahapan peristiwa sehingga menjalani suatu cerita yang dihadirkan oleh para pelaku dalam cerita. Hal yang sama dikemukakan oleh Oemaryati (1962:94) yang mengatakan alur adalah struktur penyusun kejadian-kejadian dalam cerita yang disusun secara logis. Jadi, alur adalah rangkaian peristiwa atau tahapan peristiwa dalam cerita melalui rumitan ke arah klimaks dan selesaian.

Menurut Semi (1988:48), tokoh ialah pelaku dalam karya sastra. Dalam karya sastra biasanya ada beberapa tokoh, namun hanya ada satu tokoh utama. Tokoh utama ialah tokoh yang sangat penting dan menjadi peran utama dalam karya sastra. Istilah tokoh menunjuk pada orangnya, pelaku cerita, misalnya sebuah pertanyaan, siapa tokoh utama cerpen itu? Siapakah tokoh protagonis cerpen tersebut? Dan bentuk-bentukpertanyaan lain.

Penokohan; watak; perwatakan menunjuk pada sifat dan sikap para tokoh seperti yang ditafsirkan oleh pembaca atau lebih menunjuk pada kualitas pribadi tokoh. Dengan demikian, istilah penokohan lebih luas pengertiannya daripada tokoh, sebab pengertian ini mencakup masalah siapa tokoh dalam cerita, bagaimana perwatakannya, dan bagaimana penempatan dan pelukisannya dalam sebuah cerita sehingga sanggup memberikan gambaran yang jelas kepada pembaca.

Pengertian latar, Yudhiono (1981:35) mengemukakan latar adalah lukisan atau gambaran mengenai ruang atau waktu 
terjadinya peristiwa. Selanjutnya, Aminudin (1987:67) menyatakan setting ialah latar belakang peristiwa dalam karya fiksi berupa tempat, waktu, peristiwa, serta memiliki fisikal dan psikologi.

Mengenai unsur gaya bahasa, Semi (1988:48) mengemukakan gaya bahasa atau gaya penceritaan adalah tingkah laku pengarang dalam menggunakan bahasa tersebut menyangkut pilihan materi bahasa, pemakaian ulasan dan pemanfaatan gaya bertutur. Menurut Sumardjo dkk. (1986:127) bahwa gaya bahasa adalah cara menggunakan bahasa agar daya ungkap atau daya tarik sekaligus keduanya bertambah.

\subsection{Pendidikan Karakter}

Menurut Michael Novak karakter merupakan "campuran kompatibel dari seluruh kebaikan yang diidentifikasi oleh tradisi religius, cerita sastra, kaum bijaksana, dan kumpulan orang berakal sehat yang ada dalam sejarah." Sementara itu, Masnur Muslich menyatakan bahwa karakter merupakan nilai-nilai perilaku manusia yang berhubungan dengan Tuhan Yang Maha Esa, diri sendiri, sesama manusia, lingkungan, dan kebangsaan yang terwujud dalam pikiran, sikap, perasaan, perkataan, dan perbuatan berdasarkan norma-norma agama, hukum, tata krama, budaya, dan adat istiadat.

Selanjutnya, Muchlas Samani berpendapat bahwa karakter dapat dimaknai sebagai nilai dasar yang membangun pribadi seseorang, terbentuk baik karena pengaruh hereditas maupun pengaruh lingkungan, yang membedakannya dengan orang lain, serta diwujudkan dalam sikap dan perilakunya dalam kehidupan sehari-hari.

Karakter adalah ciri khas yang dimiliki oleh suatu benda atau individu. Ciri khas tersebut asli dan mengakar pada kepribadian benda atau individu tersebut, dan merupakan mesin yang mendorong bagaimana seseorang bertindak, bersikap, berujar, dan merespon sesuatu.

\section{METODE PENELITIAN}

Penelitian ini merupakan penelitian kualitatif dengan menggunakan analisis isi. Dalam penelitian ini, informasi yang bersifat kualitatif dideskripsikan secara teliti dan analitis. Pendekripsian meliputi mencatat dan menganalisis Buku Cerita Bergambar "Pajak Kita" mengenai unsur instrinsik cerita. Novel Buku Cerita Bergambar "Pajak Kita” tersebut diteliti berkaitan dengan unsur 
instrinsik dan nilai karakter serta relevansinya tehadap kemajuan Bangsa Indonesia ini.

Data penelitian diperoleh melalui membaca Buku Cerita Bergambar "Pajak Kita". Sumber data penelitian ini adalah dokumen. Teknik sampling yang digunakan adalah purposive sampling. Teknik yang digunakan dalam pengumpulan data adalah analisis dokumen.

Validitas data diperoleh dengan cara triangulasi. Triangulasi adalah teknik pemeriksaan keabsahan data yang memanfaatkan sesuatu yang lain di luar data itu untuk keperluan pengecekan atau sebagai pembanding terhadap data itu. Validitas data dalam penelitian ini dilakukan melalui triangulasi teori dan triangulasi sumber. Triangulasi teori untuk mengecek kebenaran data berdasarkan perspektif teori yang berbeda. Triangulasi sumber dilakukan dengan menggunakan informasi dari beberapa informan.

Teknik analisis data yang digunakan dalam penelitian ini adalah model analisis interaktif (interactive model of analysis). Analisis model interaktif ini merupakan interaksi dari empat komponen, yaitu pengumpulan data, reduksi data, penyajian data, dan penarikan simpulan.

\section{PEMBAHASAN}

\subsection{Buku Cerita Bergambar "Pajak Kita"}

Anak-anak pada usia dini biasanya memiliki perilaku yang sesuai denga napa yang diajarkan oleh orang tuanya juga perilaku yang diajarkan oleh lingkungan sekitarnya. Masa anak-anak adalah masa yang sangat ideal bagi orang tua dalam menanamkan nilai-nila moral, budi pekerti, maupun nila sosial serta pembentukan karakter pada anak-anak.

Salah satu cara untuk menanamkan nila-nilai yang bak serta pendidikan karakter pada anak usia dini adalah fabel. Fabel merpakan cerita yang menggambarkan watak budi manusia yang pelakunya diperankan oleh binatang. Fabel ini mengandung nilanilai pendidikan moral dan budi pekerti. Melalui fabel, kita dapat menyiapkan nilainilai moral yang ingin orang tua tanamkan sejak anak usia dini.

Buku Cerita Bergambar "Pajak Kita" merupakan salah satu buku bergambar atau fabel yang ditulis dengan tujuan untuk memperkealkan kepada anak usia dini tentang perpajakan. Buku cerita bergambar iniberisi tiga cerita fabel yang inspriratif, 
yaitu kisah raja lebah dan satu sendok madu, kisah anjing dan kelinci, dan kisah semut dan jangrik. Dalam cerita tersebut, tedapat nilainilai moral yang ingin disampakan, seperti kejujuran, keteladanan, kedisiplinan, tanggungjawab, ketekunan, kerja keras, kepatuhan, ketertiban keadilan, loyalitas, dan sebagainya.

\subsection{Struktur Pembangun Buku Cerita Begambar "Pajak Kita"}

Ketidakpuasan terhadap formalisme, menyebabkan munculnya paham strukturalisme. Paham ini beranggapan yang membentuk sastra bukan hanya bahasanya, melainkan struktur. Bahasa dalam sastra mungkin saja tidak terlalu berbeda dengan bahasa sehari-hari, namun struktur-struktur pembentuk dalam sastra itu sendiri tetap. Artinya, selama struktur-struktur pembentuk sastra itu terpenuhi, maka sebuah karya bisa dianggap sebagai bagian dari sastra.

Unsur atau krtuktur pembentuk dalam Buku Cerita Bergambar "Pajak Kita" ini adalah unsur instrinsik dan ekstrinsik. Unsurunsur yang terdapat pada buku cerita ini akan dijelaskan sebagai berikut.

\section{Unsur Tema}

Pada Buku Cerita Bergambar "Pajak Kita" terdapat tiga cerita setiap cerita megusung tema yang berbeda. Tema-tema dalam ketiga cerita tesebut adalah sebagai berikut:

a. Tema Cerita berjudul "Raja Lebah dan Sesendok Madu"

Tema dari cerita ini adalah "keujuran dan kebijaksanaan". Hal ini dapat dilihat dari isi cerita yang menggambarkan seorang raja lebah di kerajaan lebah yang memiliki banyak rakyat, namun ketika rakyat diminta mengumpulkan madu yg akan dibagikan kembali untuk rakyat, ternyata rakyatnya melakukan kecurangan yang pada akhirnya menjadi pelajaran bagi rakyat dari kerajaan itu sendiri.

b. Tema Cerita berjudul "Anjing dan Kelinci"

Tema dari cerita ini adalah "permintaan maaf" hal ini dapat dilihat dari isi cerita, yang mana seorang kelinci diam-diam telah memakan tanaman wortel yang dijaga oleh seekor anjing, lalu kemudian kelinci tersebut menyadari kesalahannya sehingga kelinci tesebut meminta maaf.

c. Tema Cerita berjudul " Semut dan Jangkrik"

Tema dari cerita ini adalah "rajin dan tekun", hal ini dapat dilihat dari isi cerita yang mana ada sekelompok semut yang 
mencari makan di siang hari dengan penuh semangat dan tekun. Di sisi lain, ada seekor jangkrik yang setiap siang hanya tidur dan bermalas-malasan. Setiap malam semut tidur, namun jangkrik tebangun serta bernyanyi tanpa bekerja mengumpulkan makanan. Hingga suatu hari, tejadi musim kemarau panjang. Semut telah mengumpulkan banyak makanan sehingga semut tidak merasa khawatir akan kelaparan, dan sebaliknya, jangkrik merasa kelaparan karena jangkrik malas dan tidak mau mengumpulkan makanan. Akhirnya, semut memberikan simpanan makanan yang dimiliki semut kepada jangkrik, sehingga jangkrik meyadari bahwa sangat penting untuk tekun dan rajin dalam mempersiapkan kemungkinankemungkinan yang tejadi di mmasa yang akan datang.

\section{Alur}

Pengertian alur, Sudjiman (1992:43) berpendapat bahwa alur adalah rangkaian peristiwa yang direka dan dijalani dengan saksama yang menggerakkan cerita melalui rumitan ke arah klimaks dan selesaian. Alur yang tedapat pada ketiga cerita dalam Buku Cerita Bergambar "Pajak Kita" adalah alur yang sangat sederhana, yaitu alur "maju".
Pemilihan alur yang sangat sederhana oleh penulis disebabkan oleh sasaran pembaca buku ini adalah anak-anak usia dini. Dengan alur yang sederhana, anak akan lebih mudah memahami isi dan makna yang disampaikan dalam cerita.

\section{Tokoh}

Menurut Semi (1988:48), tokoh ialah pelaku dalam karya sastra. Istilah tokoh menunjuk pada orangnya, pelaku cerita, misalnya sebuah pertanyaan, siapa tokoh utama cerpen itu? Siapakah tokoh protagonis cerpen tersebut? Dan bentukbentukpertanyaan lainnya. Tokoh-tokoh yang terdapat dalam ketiga cerita pada Buku Cerita Bergambar "Pajak Kita" adalah sebagai berikut.

a. Tokoh dalam Cerita berjudul "Raja Lebah dan Sesendok Madu"

1. Sang Raja

Kutipan 1 :"Wahai rakyatku, besok adalah pesta panen raya. Kalian diwajibkan untuk mengumpulkan madu satu sendok saja dari setiap tempayan madu di rumah kalian," titah sang raja

\section{Bapak Lebah}

Kutipan 1 :'Tapi Bu, raja kita kan hanya meminta satu sendok saja, 
bukannya satu tempayan," jawab

Bapak Lebah.

3. Ibu Lebah

Kutipan 1: Ibu lebah menahan, "Pak, madu itu untuk persediaan makan kita."

4. Rakyat Lebah

Kutipan 1: Rakyat lebah merasa bersalah dan menyesali perbuatannya.

b. Tokoh dalam berjudul "Anjing dan Kelinci"

1. Adik Kelinci

Kutipan 1 :Saat bersembunyi adik kelinci tergiur dengan wortel segar yang ada di hadapannya, ternyata di balik pagar itu ada kebun wortel.

2. Kakak Kelinci

Kutipan 1 : Belum jauh berlari, kaka kelinci menghetikan adik kelinci dan bertanya "Kenapa kamu bersembunyi di kebun dan memakan yang bukan milikmu?"

3. Tuan Anjing

Kutipan 1 : Dengan cepat, anjing menggonggong memergokinya.

c. Tokoh dalam berjudul "Semut dan Jangkrik"

1. Sekumpulan semut

Kutipan 1 : Sekumpulan semut sudah berbaris rapi unntuk bekerja mencari makanan

2. Jangkrik

Kutipan 1: Jangkrikpun terbangun dan membuka jendela sambal melengok, kemudian berteriak "Woooii, kalian telah mengganggu tidurku."

3. Salah satu semut

Kutipan 1: Salah satu semut menghampiri jangkrik dan berkata "Maaf kalau kami telah mengganggumu, tetapi hari sudah siang saatnya bangun dan bekerja."

\section{Penokohan}

Penokohan; watak; perwatakan menunjuk pada sifat dan sikap para tokoh seperti yang ditafsirkan oleh pembaca atau lebih menunjuk pada kualitas pribadi tokoh. Dengan demikian, istilah penokohan lebih luas pengertiannya daripada tokoh, sebab pengertian ini mencakup masalah siapa tokoh dalam cerita, bagaimana perwatakannya, dan bagaimana penempatan dan pelukisannya dalam sebuah cerita sehingga sanggup memberikan gambaran yang jelas kepada pembaca. Watak setiap tyokoh pada cerita, adalah sebagai berikut: 
d. Tokoh dalam Cerita berjudul "Raja Lebah dan Sesendok Madu"

5. Sang Raja dengan watak yang bijaksana

Berikut kutipan pendukungnya:

Kutipan 1 : Keesokan harinya menjelang pesta dimulai, Sang Raja bersabda, "Wahai rakyatku, saya perintahkan kalian untuk mengumpulkan madu ini bukanlah untuk saya sendiri, tapi madu ini akan kita gunakan untuk pesta panen raya....."

6. Bapak Lebah dengan watak jujur dan penurut terhadap istri

Berikut kutipan pendukung:

Kutipan 1 :"Tapi Bu, raja kita kan hanya meminta satu sendok saja, bukannya satu tempayan," jawab Bapak Lebah.

7. Ibu Lebah dengan watak tidak jujur/licik Kutipan 1: "Bagaima kalau madu itu kita ganti dengan sesendok air? Pasti tidak aka nada yang tahu," usul Ibu Lebah.

8. Rakyat Lebah dengan watak yang tidak jujur namun rendah hati

Kutipan 1: Rakyat lebah merasa bersalah dan menyesali perbuatannya.

e. Tokoh dalam berjudul "Anjing dan Kelinci"
4. Adik Kelinci dengan watak penakut dan rendah hati

Kutipan 1 :Adik kelinci yang sedang asyik bersembunyi dan makan wortel itu terkejut langsung lari terbiritbirit.

5. Kakak Kelinci dengan watak bijaksana dan pemberani

Kutipan 1 : "Ayo kita kembali ke kebun sekarang, untuk meminta maaf'

6. Tuan Anjing dengan watak pemaaf dan bijaksana

Kutipan 1 : Tuan ajing mmeyambut dengan baik keberanian mereka.

f. Tokoh dalam berjudul " Semut dan Jangkrik"

5. Sekumpulan semut dengan watak rajin bekerja, pekerja keras dan penuh semangat gotong royong

Kutipan 1 : Sekumpulan semut sudah berbaris rapi unntuk bekerja mencari makanan

6. Jangkrik dengan watak pemalas dan cepat marah

Kutipan 1: Jangkrikpun terbangun dan membuka jendela sambal melengok, kemudian berteriak "Woooii, kalian telah mengganggu tidurku." 
7. Salah satu semut dengan watak bijaksana dan pemurah

Kutipan 1 : Salah satu semut menghampiri jangkrik dan berkata "Maaf kalau kami telah mengganggumu, tetapi hari sudah siang saatnya bangun dan bekerja."

\section{Latar}

Latar waktu dan tempat pada ketiga cerita dalam buku cerita bergambar "Pajak Kita" adalah sebagai berikut.

a. Latar dalam Cerita berjudul "Raja Lebah dan Sesendok Madu"

1) Latar tempat

a. Di sebuah kerajaan

Kutipan 1 : Pada suatu hari, di sebuah kerajaan lebah yang tentram dan damai.

b. Di rumah Ibu dan Bapak Lebah

Kutipan 1 : sesampai di rumah, disaat Bapak Lebah akan mengambil sesendok madu.

c. Di tempat pengumpulan madu Kutipan 1 : dengan hati-hati Bapak Lebah membawa sesendok air di tempat pengumpulan madu.

d. Ruang penyimpanan

Kutipan 1 : Sang Raja langsung memerintahkan prajutir untuk meyimpan tempayan besar tersebut di dalam ruang penyimpanan.

2) Latar suasana

a. Suasana tentram dan damai

Kutipan 1 : Pada suatu hari, di sebuah kerajaan lebah yang tentram dan damai.

b. Suasana sedih dan mengejutkan

Kutipan 1 : Ketika tempayan dibuka, raja terkejut dan sedih melihat tempayan tersebut hanya berisi air.

c. Suasana cukacita

Kutipan 1 : pada perayaan musim selanjutnya rakyat bersukacita mengumpulkan lebih dari sesendok madu

b. Latar dalam berjudul "Anjing dan Kelinci”

1) Latar tempat

a. Di balik pagar kebun

Kutipan 1 : salah satu dari mereka bersembunyi di balik pagar kebun.

b. Di kebun wortel

Kutipan 1 : Tenyata di balik pagar itu ada kebun wortel.

Kutipan 2: sesampainya di kebun dan meemui anjing tersebut.......

2) Latar suasana

a. Suasana pagi yang cerah

Kutipan 1 : pagi yang cerah, beberapa 
kelinci berlarian sedang asyik bermain petak umpet.

b. Suasana penuh ketegangan

Kutipan 1 : Adik kelinci yang sedang asyik bersembunyi dan memakan wortel terkejut dan langsung lari terbirit-birit.

c. Latar dalam berjudul "Semut dan Jangkrik"

1) Latar tempat

a. Di balik jendela

Kutipan 1: Jangkrik pun terbangun dan membuka jendela sambal melongok.

2) Latar suasana

a. Suasana pagi yang cerah

Kutipan 1 : pagi yang cerah, matahari mulai mengintip dari langit timur.

b. Suasana malam hari

Kutipan 1 : menjelang malam tiba.

c. Suasana musim kemarau

Kutipan 1 : Tanpa terasa, tibalah musim kemarau, jangkrik mulai kehausan dan kelaparan

\section{Amanat}

Amanat merupakan pesan yang ingin disampakan penulis kepada pembaca. Berikut merpakan amanat yang terdapat dalam ketiga cerita dalam Buku Cerita Bergambar "Pajak Kita".

a. Amanat dalam cerita Raja Lebah dan Sesendok Madu adalah penulis ingin menyampakan kepada pembaca agar kita selalu bersikap jujur dan penulis juga ingin meyampakan bahwa apapun yang kita berikan kepada kerajaan yang dalam hal ini dapat dikatakan negara maka akan dinikmati sediri oleh rakyat.

b. Amanat yang terkandung dalam cerita Anjing dan Kelinci adalah penulis ingin meyampakan pesan bahwa pembaca tidak boleh mengambil apapun yang bukan haknya, seperti yang dilakukan oleh adik kelinci. Mengambil milik orang lain tanpa izin adalah sesuatu yang salah dan mengakibatkan hal yang tidak baik. Penulis juga ingin menyampakan bahwa, jujur dan bersedia mengakui kesalahan adalah hal yang mulia.

c. Amanat yang tekandung dalam cerita Semut dan Jangkrik adalah peulis ingin meyampaikan pesan bahwa pembaca harus selalu semangat bekerja, rajin bekerja, dan rajin menabung untuk persiapan di masa yang akan datang. Penulis juga ingin meyampakan bahwa sikap pemalas seperti jangkrik dalam cerita ini sangatlah tidak baik. Sikap 
pemalas akan menimbulkan kesusahakn dimasa yang akan datang.

\subsection{Nilai Pendidikan Karakter dalam Buku Cerita Bergambar "Pajak Kita"}

1. Nilai Pendidikan Karakter dalam Cerita Raja Lebah dan Sesendok Madu

Ada beberapa nilai moral yang dapat kita ambil dari cerita raja lebah dan sesendok madu, nilai - nilai moral tersebut antara lain kejujuran dan kepatuhan cerita tersebut mengisahkan rakyat yang bersipat tidak jujur dan tidak patuh dalam menjalankan perintah raja,rakyat mengganti sesendok madu dengan sesendok air. Tindakan rakyat ini mengakibatkan gagalnya pesta panen raya yang sebelumnya sudah direncanakan oleh sang raja.

2. Nilai Pendidikan Karakter dalam Cerita Semut dan Jangkrik

Ada beberapa nilai moral yang dapat kita teladani dari kisah semut dan jangkrik.nilai - nilai moral tersebut antara lain kerja keras, ketekunan, kerja sama ,kedisiplinan, tanggung jawab,ketulusan / keiklasan dan kemandirian. Cerita tersebut mengisahkan tentang sekelompok semut yang pekerja keras ,suka bekerja sama, tekun, disiplin dan penuh tanggung jawab dalam bekerja demi mengumpulkan makanan.

3. Nilai Pendidikan Karakter dalam Cerita Anjing dan Kelinci

Ada beberapa nilai moral yang dapat kita teladani dari kisah anjing dan kelinci, nilai-nilai moral tersebut antara lain kesetiaan, kepatuhan dan kedisiplinan. cerita tersebut mengisahkan seekor anjing yang mempunyai tugas menjaga kebun wortel milik majikannya dari berbagai gannguan,ia begitu setia,patuh,dan juga sangat disiplin dalam menjalankan tugasnya.selan itu cerita ini juga mengandung nilai moral kejujuran,hal ini tergambar saat sang kakak klinci megetahui adiknya memakan wortel yang bukan miliknya ia megajak adiknya mengatakan yang sejujurnya dan meminta maaf kepada sang anjing.

\subsection{Relevansi Buku Cerita Bergambar "Pajak Kita" tehadap Kemajuan}

\section{Bangsa Indonesia}

Dalam buku cerita bergambar "Pajak Kita”, memerintah Indonesia dapat 161 
menanamkan rasa tanggung jawab, rasa gotong royong dan rasa toleransi terhadap sesama yang tentu akan sangat berpengaruh terhadap kemajuan negara Indonesia. Buku cerita bergambar ini berisi tiga cerita yang inspiratif,yaitu kisah raja lebah dan satu sendok madu,kisah anjing dan kelinci,kisah semut dan jangkrik dalam cerita tersebut terdapat nilai - nilai moral yang ingin disampaikan seperti kejujuran, keteladanan, kedisiplinan, tanggung jawab, ketekunan, kerja keras, kepatuhan, ketertiban, keadilan, loyalitas, ketulusan dan sebagainya. Nilai nilai tersebut juga merupakan nilai - nilai moral yang berlaku dalam kehidupan berbangsa dan bernegara khususnya dalam kaitannya dengan pemenuhan kewajiban perpajakan,

Dengan ditanamkannya nilai-nila yang baik dalam diri anak sejak usia dini, generasi penerus bangsa Indonesia ini tetu akan paham betul mengenai hal-hal yang berkatan dengan kemajuan negara. Salah satunya mengenai pembayaran pajak. Salah satu cerita yang sangat relevan tehadap pembayaran pajak adalah cerita "Sang Raja dengan Sesendok Madu”. Cerita ini mengajarkan pembaca khususnya anak usia dini bahwa apa yang kita berika kepada negara dalam betuk pajak adalah untuk diri mereka sediri, sama halnya dengan rakyat dalam cerita tersebut yang mempersembahkan madu kepada rajanya yang tenyata madu tesebut akan dinikmati Bersama-sama oleh selurh rakyat. Begitu halnya dengan membayar pajak yang tentu akan dinimkati sendiri oleh rakyar dan demi kemajuan bangsa dan negara ini. Dengan cerita ini, seak dini anak-anak akan paham betul dengan pentingnya membayar pajak sehingga negara dan bangsa ini akan maju dan berkembang dengan baik.

\section{PENTUTUP}

Simpulan yang dapat ditarik dari penelitian ini adalah sebagai berikut.

1. Buku Cerita Bergambar "Pajak Kita" memiliki unsur instrinsik, yaitu unsur dalam pembangun sebuah karya sastra. Unsur-unsur tesebut adalah unsur tema, amanat, latar, alur, tokoh, dan penokohan.

2. Ketiga cerita dalam Buku Cerita Bergmabar "Pajak Kita" mengandung nilai-nila pendidikan karakter yang tergambar jelas dalam cerita. Nilai-nila tesebut adalah nilai tanggung jawab, nilai kerja keras, ketekunan, kerja sama ,kedisiplinan, keiklasan dan kemandirian, nila gotong royong, dan 
lain-lan. Nila-nila ini sangat berpengaruh besar tehadap perkembangan karakter anak sejak dini.

3. Buku Cerita Begambar "Pajak Kita" sangat relevan dengan perkembangan Bangsa Indonesia. Dalam cerita yang tedapat pada buku bergambar ini mengajarkan nilai-nila karakter yang positif yang tentu akan berpengaruh besar terhadap perkebangan Bangsa Indonesia kelak. Salah satu yang paling relevan adalah cerita dengan judul "Sang Raja dengan Sesendok Madu" Cerita ini sangat berkaitan erat dengan pembayaran pajak di negara kita, yang mana membayar pajak adalah salah satu tanggung jawab rakyat yang nantinya akan dinikmati sediri oleh rakyat. Cerita ini tentu akan menjadi pengaruh besar terhadap rasa tanggung jawab anak yang nantinya akan diaplikasikan ketika anak sudah besar.
Sekolah Tinggi Keguruan Dan Ilmu Pendidikan Agama Hindu.

Kaelan. 2010. Metode Penelitian Agama Kualitatif Interdisipliner. Yogyakarta: Paradigma.

Nurgiyantoro, B. 2005. Teori Pengkajian Fiksi. Yogyakarta: Gadjah Mada University Press.

Waluyo, H.J. 2011. Pengkajian dan Apresiasi Prosa Fiksi. Surakarta: Sebelas Maret University Press.

Wardani, N.E. 2009. Makna Totalitas dalam Karya sastra. Surakarta: Universitas Sebelas Maret Press.

Winkel, W. S. 1999. Psikologi Pengajaran. Jakarta: PT Grasindo.

Zubaedi. 2011. Desain Pendidikan Karakter: Konsepsi dan Aplikasinya dalam Lembaga Pendidikan. Jakarta: Kencana.

Zuhdi, D. 2009. Pendidikan Karakter. Yogyakarta: UNY Press.

\section{DAFTAR PUSTAKA}

Dwija, I Wayan. 2006. Metodologi Penelitian Pendidikan. Amlapura : Sekolah Tinggi Keguruan dan Ilmu Pendidikan Agama Hindu.

------. 2016. MetodologiPenelitian Pendidikan (Bahan Ajar). Amlapura: 